\title{
Infestasi caplak pada ternak kuda di desa Pinabetengan Raya, Kecamatan Tompaso Barat, Kabupaten Minahasa, Provinsi Sulawesi Utara
}

\author{
A.P. Ariman, M.J. Nangoy*, Y.L.R. Tulung, G.V.J. Assa \\ Fakultas Peternakan Universitas Sam Ratulangi Manado 95115 \\ *Korespondenensi (corresponding author): mnangoy@unsrat.ac.id
}

\begin{abstract}
ABSTRAK
Penelitian ini bertujuan mengidentifikasi jenis caplak, menghitung prevalensi infestasi caplak, preferensi infestasi bagian tubuh dan preferensi infestasi jenis kelamin pada ternak kuda di Desa Pinabetengan Raya, Kecamatan Tompaso Barat, Kabupaten Minahasa, Provinsi Sulawesi Utara. Penelitian ini dilakukan selama 1 (satu) bulan pada 50 ekor ternak kuda. Pengambilan caplak dilakukan secara manual menggunakan pinset secara berurut mulai dari bagian kepala, leher, punggung, abdomen, selangkangan, ekor, dan kaki. Sampel dimasukkan dalam botol berisi alkohol $70 \%$. Hasil penelitian ini ditemukan bahwa jenis caplak yang menginfestasi ternak kuda adalah Boophilus microplus. Prevalensi infestasinya 60,78\%. Preferensi berdasarkan bagian tubuh ditemukan paling tinggi di bagian leher rata-rata 2,82 individu caplak/kuda. Di kepala rata-rata 1,75, punggung rata-rata 0,25 , abdomen rata-rata 0,72 , selangkangan rata-rata 1,27, kaki rata-rata 0,25 dan ekor rata-rata 0,74 individu caplak/kuda. Preferensi infestasi berdasarkan jenis kelamin ditemukan betina lebih tinggi (rata-rata 10,48 individu caplak/kuda) bila dibandingkan jantan (rata-rata 2,64 individu caplak/kuda). Indetifikasi jenis caplak yang ditemukan adalah Boophilus microplus dengan Prevalensi infestasi sebesar $62 \%$, dengan preferensi tertingi pada bagian leher dengan rata-rata $2,82 \%$ dan kuda betina lebih tinggi dengan rata-rata $10,48 \%$ individu caplak/ternak kuda.
\end{abstract}

Kata Kunci : Caplak, Infestasi, Prevalensi, Preferensi, Kuda.

\begin{abstract}
This study aims to identify the types of ticks, calculate the prevalence of tick infestations, preferences for body part infestations and preferences for sex infestations in horses in Pinabetengan Raya Village, West Tompaso District, Minahasa Regency, North Sulawesi Province. This research was carried out for one month (thirty days) on 50 horses. Ticks are collected manually using tweezers in sequence starting from the head, neck, back, abdomen, groin, tail and legs. The samples were put in bottles containing $70 \%$ alcohol. The results of this study found that the type of tick that infested horse livestock was Boophilus microplus. The prevalence of infestation is $60.78 \%$. The preference based on body part was found to be highest in the neck with an average of 2.82 individual ticks / horses. The average head was 1.75, the back was 0.25 , the abdomen was 0.72 , the groin was 1.27 , the legs were 0.25 and the tail was 0.74 of the individual ticks/horse. Infestation preference based on sex was found to be higher for females (average 10.48 individual ticks / horse) when compared to males (mean 2.64 individual ticks/horse). The type identification found was Boophilus microplus with an infestation prevalence of $62 \%$, with the highest preference on the neck with an average of $2.82 \%$ and higher mares with an average of $10.48 \%$ individual ticks/horse livestock.
\end{abstract}


Keywords : Ticks Infestation, Prevalence, Preference, Horse.

\section{PENDAHULUAN}

Kuda adalah salah satu hewan liar yang telah terdomestikasi. Masyarakat Minahasa khususnya yang berdomisili di Kecamatan Tompaso Barat, Kabupaten Minahasa, Sulawesi Utara pada umumnya beternak kuda untuk dipekerjakan sebagai alat transportasi (kuda bendi), dan hewan kesayangan sebagai kuda pacu (Turangan, 2017). Ternak juga dapat menjadi alternatif penyedia daging dan mempunyai potensi yang cukup besar sebagai salahsatu sumber pangan yang mempunyai kandungan protein yang sangat tinggi (Sihite et al., 2018). Daging kuda memiliki banyak khasiat, salah satunya adalah untuk menambah stamina dan gairah. Di luar itu, bisa juga untuk membantu mengatasi risiko asam urat, rematik, kencing manis, asma sampai gatal eksim. Karena kuda termasuk binatang yang suka bergerak, kolesterolnya pun menjadi sangat rendah (Hotabilatdur $e t$ al., 2013)

Desa Pinabetengan merupakan salah satu desa di Provinsi Sulawesi Utara yang merupakan sentra pengembangan ternak kuda. Di Desa ini terdapat beberapa stable yang telah dikelola secara profesional akan tetapi dapat pula ditemukan sebagian penduduknya memelihara kuda dengan secara terbatas atau berdasarkan pengalaman dan belum memperhatikan tatalaksana pemeliharaan ternak yang baik dan benar.

Populasi kuda di Indonesia mengalami penurunan karena penyakit. Kuda yang tidak terawat dengan baik sangat rentan terhadap serangan berbagai penyakit (Murwani et al., 2017; Wibawa, 2019). Pengobatan penyakit kuda cenderung membutuhkan lebih banyak tenaga, waktu dan biaya, sehingga diperlukan campur tangan dari tenaga ahli. Oleh karena itu status dan kondisi kesehatan hewan harusnya dapat dikendalikan (Kurniadi, 2017) sehingga populasi dapat ditingkatkan. Indonesia sebagai salah satu negara beriklim tropis memiliki permasalahan yang besar akibat infestasi ektoparasit di peternakan. Keberadaan ektoparasit tersebut semakin merugikan apabila tidak dikendalikan dengan baik contohnya caplak (Subronto, 2003).

Ektoparasit merupakan vektor penularan penyakit dari hewan ke hewan lain maupun ke manusia. Berbagai jenis ektoparasit dikenal sebagai vektor zoonosis yang berakibat fatal bagi manusia (Annashr et al., 2011). Beberapa ektoparasit yang sangat merugikan usaha peternakan antara lain caplak (Harun, 2015). Infestasi caplak (Boophilus microplus) pada ternak sapi di Kecamatan Tompaso ditemukan tinggi. Hasil penelitian prevalensi caplak di desa Tolok 100\% (Patodo et al., 2018) dan di desa Pinabetengan prevalensinya 46,9\% (Konore et al., 2019). Oleh karena itu telah dilakukan penelitian ini untuk mengetahui prevalensi infestasi caplak dan preferensi berdasarkan bagian tubuh serta jenis kelamin ternak untuk kepentingan pengendalian caplak pada ternak kuda.

Penelitian ini bertujuan untuk mengidentifikasi jenis caplak, menghitung prevalensi infestasi caplak, menghitung preferensi infestasi caplak menurut bagian tubuh dan menghitung preferensi infestasi caplak berdasarkan jenis kelamin pada ternak kuda.

\section{MATERI DAN METODE PENELITIAN}

Penelitian dilakukan selama 1 (satu) bulan berlokasi di Desa Pinabetengan Raya, Kecamatan Tompaso Barat, Kabupaten Minahasa, Sulawesi Utara. Penelitian ini menggunakan metode purposive sampling yaitu pengambilan sampel ternak kuda yang terpilih berdasarkan hasil survey yakni ternak kuda dewasa yang berumur 27 tahun keatas dengan sistem pemeliharaan 
secara tradisional. Tahap penelitian diawali dengan pra penelitian selama 1 (satu) minggu dan penelitian selama 3 (tiga) minggu. Sejumlah 50 ekor ternak kuda yang terdiri dari 25 ekor jantan dan 25 ekor betina dengan sistem pemeliharaan secara tradisional (berdasarkan pengalaman sendiri) dijadikan sampel penelitian. Alat yang digunakan dalam penelitian ini antara lain sarung tangan, pinset, masker, botol sampel, mikroskop, kamera digital, alat tulis, alkohol $70 \%$. Pengumpulan caplak dilakukan dengan cara manual menggunakan pinset secara berurutan dimulai dari bagian kepala, leher, punggung, perut atau abdomen, selangkangan, kaki dan ekor. Sampel yang terkumpul dimasukkan ke dalam botol yang berisi alkohol $70 \%$ dan berlabel nomor ternak jenis kelamin, dan bagian tubuh kuda. Caplak yang terkumpul dilakukan identifikasi menggunakan kunci identifikasi buku ektoparasit (pengenalan, identifikasi dan pengendalianya) (Hadi dan Soviana, 2010) di Laboraturium Fakultas Peternakan, Universitas Sam Ratulangi Manado dan verifikasi di Laboratorium Entomologi Veteriner Fakultas Kedokteran Hewan Institut Pertanian Bogor.

Variabel dalam Penelitian adalah :

- Jenis caplak pada ternak kuda

- Prevalensi infestasi caplak pada kuda yaitu prensentasi jumlah kuda yang terinfestasi caplak di desa Pinabetengan raya, dengan rumus yang di pakai oleh Husna (2014) yaitu : Prevalensi= $\frac{\text { jumlah kuda yang terinvestasi }}{\text { jumlah kuda yang diamati }}$ X 100\%

- Preferensi insfestasi caplak menurut bagian tubuh kuda, (rata-rata caplak di setiap bagian tubuh kuda). Preferensi = bagian tubuh kuda yang terinvestasi

jumlah kuda yang diamati

- Preferensi infestasi caplak menurut jenis kelamin kuda ( rata-rata caplak yang terdapat pada kuda). Preferensi = jenis kelamin kuda yang terinvestasi jenis kelamin kuda yang diamati

\section{HASIL DAN PEMBAHASAN}

\section{Caplak Boophilus microplus pada ternak kuda}

Total caplak yang di dapatkan dalam penelitian ini berjumlah 328 individu caplak dan jenis caplak yang ditemukan dalam penelitian ini yaitu caplak Boophilus microplus (gambar 1 dan 2). Boophilus microplus adalah species caplak sub genus Boophilus, genus Rhipicephalus family Ixodidae (Leliana dan Rizalsyah, 2015). Caplak ini terdapat di negara tropis dan subtropis (Labruna et al., 2010). Caplak dapat menyebabkan ancaman yang signifikan terhadap kesehatan kuda selain menyebabkan kurus, iritasi, luka kulit, alergi, dan kehilangan darah (Duell et al., 2013). Caplak Boophilus microplus merupakan caplak yang merugikan karena selain mengisap darah, Caplak berperanan juga sebagai vektor (Sahara et al., 2015). berbagai penyakit yang disebabkan oleh bakteri, virus, protozoa dan rickettsia. Beberapa di antaranya bersifat zoonosis (Biru et al., 2018). Adanya caplak disebabkan sistem pemeliharaan sangat berperan penting dalam kesehatan ternak. Sistem pemeliharaan secara ekstensif lebih dominan terserang ektoparasit caplak dibandingkan dengan sistem pemeliharaan intensif dan semi intensif.

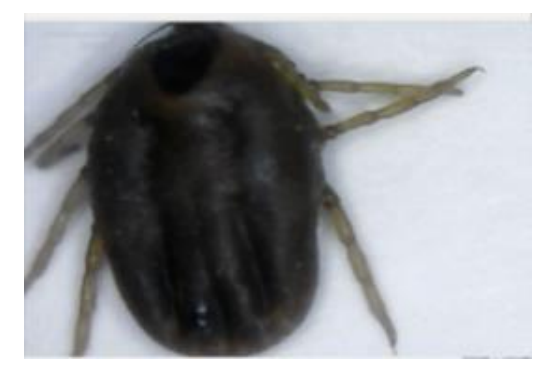

Gambar 1. Boophilus microplus 


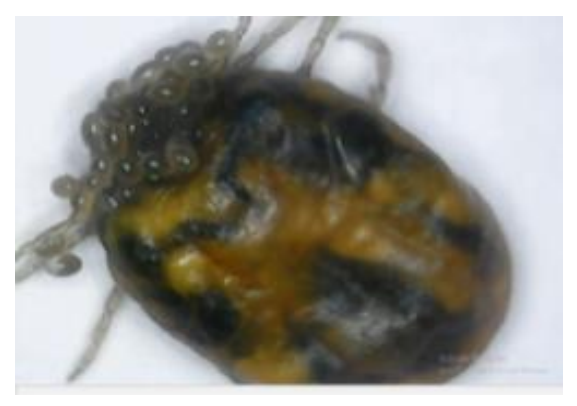

Gambar 2. Boophilus microplus yang bertelur

\section{Prevalensi infestasi caplak (Boophilus microplus) pada ternak kuda}

Hasil penelitian prevalensi infestasi caplak Boophilus microplus pada ternak kuda diperoleh bahwa $62 \%$, yaitu sebanyak 31 ekor yang terinfeksi dari 50 ekor ternak kuda.

Caplak adalah salah satu ektoparasit yang sering ditemui dan mampu menurunkan kualitas dan kuantitas produk peternakan. Diperkirakan $80 \%$ produksi ternak diseluruh dunia terserang caplak (Stacey et al., 1978). Ternak kuda di Desa Pinabetengan terinfestasi caplak Boophilus microplus $62 \%$ karena berdasarkan hasil pengamatan pada umumnya topografi wilayah desa Pinabetengan beberapa berada pada area padang rumput yang sangat cocok bagi perkembangan parasit seperti caplak keras serta sistem pemeliharaannya masih tergolong tradisional. Daerah tropis, caplak keras yang paling banyak ditemukan yaitu Hyalomma, Boophilus, Rhipicephalus dan Amblyomma (Bala et al., 2018). Jenis caplak yang ditemukan yaitu Boophilus microplus, karena Caplak tersebut bisa di lihat secara langsung pada ternak kuda yang sudah terinfestasi, karena caplak Boophilus microplus merupakan ektoparasit yang hidupnya menumpang pada permukaan tubuh inang (host) sifatnya obligat yaitu seluruh stadiumnya mulai dari prodewasa sampai dewasa hidup bergantung pada inangnya (Natadisastra dan Agnes, 2005).

\section{Preferensi infestasi caplak (Boophilus microplus) berdasarkan bagian tubuh}

Hasil penelitian tentang preferensi infestasi caplak berdasarkan bagian tubuh ternak kuda disajikan dalam tabel 1. Data menunjukkan semua bagian tubuh terinfestasi caplak. Infestasi caplak tertinggi terdapat pada bagian leher dengan rata-rata 2,82 individu caplak/kuda dan terendah terdapat pada bagian punggung dan kaki dengan rata-rata 0,25 individu caplak/kuda. Tingginya infestasi caplak di bagian leher dengan 2,82 individu caplak pada ternak kuda karena dari hasil pengamatan di lapangan ditemukan bagian leher merupakan bagian kulit yang tipis dan tempat yang lembab serta tempat berlindungnya caplak dari inangnya. Sedangkan bagian punggung dan kaki jarang ditemukan caplak sebab, bagian

Tabel 1. Rata-Rata Preferensi Infestasi Caplak Berdasarkan Bagian Tubuh (Individu caplak/kuda)

\begin{tabular}{lc}
\hline Bagian Tubuh & Rata-rata \\
\hline Kepala & 0,25 \\
Leher & 2,82 \\
Punggung & 0,25 \\
Abdomen & 0,72 \\
Selangkangan & 1,27 \\
Kaki & 0,25 \\
Ekor & 0,74 \\
\hline
\end{tabular}


Tabel 2. Rata rata Preferensi Infestasi Berdasarkan Jenis Kelamin Ternak Kuda (Individu caplak/ kuda).

\begin{tabular}{lc}
\hline Jenis Kelamin & Rata-rata \\
\hline Jantan & 2,64 \\
Betina & 10,48 \\
\hline
\end{tabular}

tersebut bebas atau terbuka untuk para predator caplak seperti burung dan semut (Patodo et al, 2018). caplak memerlukan bagian kulit tipis dan area terlindung pada inang untuk proses penghisapan darah (Fielden dan Rechaf, 1994).

\section{Preferensi infestasi caplak (Boophilus microplus) berdasarkan jenis kelamin ternak kuda}

Hasil rata-rata preferensi infestasi berdasarkan jenis kelamin ternak kuda disajikan dalam Tabel 2. Kuda betina lebih tinggi terinfestasi caplak (Boophilus microplus) dari pada kuda jantan. Jumlah caplak pada kuda betina diperoleh rata-rata 10,48 individu caplak/kuda, sedangkan kuda jantan rata-rata 2,64 individu caplak/ kuda.

Kuda betina lebih banyak terinfestasi caplak karena dari hasil pengamatan ada beberapa kuda betina yang mengalami kebuntingan, serta ada juga yang baru beranak. Parasit dengan jumlah terbanyak pada salah satu jenis kelamin, kemungkinan karena dipengaruhi oleh faktor stres. Kuda betina sering mengalami stres apabila dibandingkan dengan kuda jantan. Kuda betina mengalami proses kebuntingan, melahirkan dan laktasi pada umumnya menyebabkan stres. Adanya faktor stres ini menimbulkan gangguan hormon pada kuda betina tersebut dan ketidak seimbangan imunitas kuda (Bandini, 1999).

\section{KESIMPULAN}

Indetifikasi jenis caplak yang ditemukan adalah Boophilus microplus salah satu species caplak dari sub genus
Boophilus dengan Prevalensi infestasi sebesar $62 \%$, dengan preferensi tertingi pada bagian leher dengan rata-rata $2,82 \%$ dan kuda betina lebih tinggi dengan ratarata $10,48 \%$ individu caplak/ternak kuda.

\section{DAFTAR PUSTAKA}

Annashr, N.N., L. Santoso, R. Hestiningsih. 2011. Study of rats and density in the Village Jomblang Ectoparasites, Candisari District, City Semarang. Jurnal Ilmiah. Wawasan Kesehatan 3(2): 23-35.

Bala, A.E., A.D. Abakar, M.S. Mohammed, F.M.I.S. Eisa. 2018. Prevalence of hard tick (Acari: Ixodidae) and preliminary observation on Babesia infection on equines in White Nile State, Sudan. International Journal of Veterinary Sciences and Animal Husbandry 3(3): 22-28.

Bandini, Y. 1999. Sapi Bali. Penebar Swadaya. Jakarta.

Biru, D., A.I.R. Detha dan D.A. Wuri 2018. Kajian pemahaman peternak dan pelaku usaha produk pangan asal hewan tentang penyakit zoonosis dan pencegahannya di Kota Kupang. Jurnal Kajian Veteriner 6(2): 85-111.

Duell, J. R., R. Carmichael, B.H. Herrin, T.C. Holbrook, J. Talley dan S.E. Little. 2013. Prevalence and species of ticks on horses in central Oklahoma. Journal of Medical Entomology 50(6): 330-1333.

Fielden L. J. dan Y. Rechav. 1994. Attachment sites of the tick Amblyomma marmoreum on its Tortoise Host, Geochelone paradalis. 
Journal. Exp. Appl. Acarol. 18(6): 3399-349.

Hadi, U.K. dan S. Soviana. 2010. Ektoparasit: Pengenalan, Diagnose, Dan Pengendalian. Institute Pertanian Bogor. PT. Penerbit IPB Press, Bogor 2010.

Harun, D. 2015. Sistem Pakar Identifikasi Ektoparasit Yang Menyebabkan Penyakit Pada Sapi. Skripsi. Jurusan Teknik Informatika Universitas Negeri Gorontalo

Hotabilatdur, W. L., T. Supriana, dan Salmiah. 2013. Beberapa faktor yang mempengaruhi permintaan daging kuda (Kasus: Kecamatan Doloksanggul, Kabupaten Humbang Hasundutan). Journal of Agriculture and Agribusiness Socioeconomics, 2(4): 1-10.

Husna, S. 2014. Evektivitas Insektisida Terhadap Larva Caplak Sapi (Boophilus Microplus) Peternakan Sapi Potong Di Jonggol Kabupaten Bogor. Skripsi. Fakultas Kedokteran Hewan, Institut Pertanian Bogor. Bogor

Konore, J.C., A. Lomboan, E. Pudjihastuti, S. Sane, M. Nangoy. 2019. Infestasi caplak (Boophilus Microplus) pada ternak sapi Di Desa Pinabetengan Kecamatan Tompaso Kabupaten Minahasa. Zootec 39(2): $387-393$.

Kurniadi, R., H. Purnomo, N. Wijayanto dan A.M. Fuah. 2017. Model pengelolaan ternak di sekitar Hutan Gunung Mutis dan dampaknya terhadap kelestarian hutan. Jurnal Ilmu Kehutanan 11(2): 156-172.

Labruna, M., N. Victoria, J. Atilio, T. Carolina. 2010. Allopatric speciation in ticks: Genetic and reproductive divergence between geographic strains of Rhipicephalus (Boophilus) microplus. BMC Evolutionary Biology 9 (1): 1-12.

Leliana L. dan T Rizalsyah. 2015. Infestasi caplak ixodidae pada sapi lokal aceh di balai pembibitan ternak unggul dan hijauan pakan ternak (BPTU-HPT) Indrapuri Kabupaten Aceh Besar. JESBIO: Jurnal Edukasi dan Sains Biologi 4(2).

Murwani, S., D. Qosimah, D. dan I.A. Amri. 2017. Penyakit Bakterial Pada Ternak Hewan Besar dan Unggas. Universitas Brawijaya Press.

Natadisastra, D. dan R. Agnes, 2005. Parasitlogi Kedokteran: Ditinjau dari Organ Tubuh yang diserang. Penerbit Buku Kedokteran EGC. Jakarta.

Patodo, G.B., M.J. Nangoy, G.J.V. Assa, A. Lomboan. 2018. Infestasi caplak pada sapi di Desa Tolok Kecamatan Tompaso Kabupaten Minahasa. Zootec 38(2): $306-313$.

Sahara, A., J. Prastowo, R. Widayanti dan W. Nurcahyo. 2015. Kekerabatan genetik caplak Rhiphicephalus (Boophilus) microplus asal Indonesia berdasarkan Sekuen Internal Transcribed Spacer-2. Jurnal Veteriner 16(3): 310-319

Sihite, I., S. Kadarsih dan D. Dwatmadji, 2018. Faktor yang Mempengaruhi Konsumsi Daging Kuda pada Rumah Tangga di Kecamatan Doloksanggul Kabupaten Humbang Hasundutan Sumatera Utara. Jurnal Sain Peternakan Indonesia 13(3): 303309.

Stacey, B.R., R.E. Williams, R.G. Buckner dan J.A. Haar. 1978. Changes in weight and blood composition of hereford and brahman steers in drylot and infeted with adult gulf coast ticks. Journal. Econ. Entomol. 71:967-970.

Subronto, S. 2003. Penyakit Infeksi Parasit dan Mikroba pada Anjing dan Kucing (end ed.). Gadjah Mada University Press.

Turangan, S.H. 2017. Penampilan ternak kuda bendi Di Kecamatan Tompaso Kabupaten Minahasa. Jurnal Zootek 37(1): $186-198$.

Wibawa, S.J. 2019. Upaya Pencegahan Penyakit Kolik Timpani Pada Hewan Ternak Kuda Di Peternakan 
Zootec Vol. 41 No. 1 : 223 - 229 (Januari 2021) $\quad$ pISSN 0852 - 2626 eISSN 2615 - 8698

Ksatria Stabel Kelurahan Wonorejo

Kecamatan Rungkut Kota Surabaya.

Dissertation. Universitas Airlangga. 